\section{APP-013 祭細胞癌における感受性遗伝子の同定}

\section{高知大学医学部腎泌尿器制御学教室 ${ }^{1}$, 高知大学医学部 環境医学教室}

山崎一郎 ${ }^{13}$, 秋丸 国広 ${ }^{2)}$, 蘆田 真吾 ${ }^{11}$, 中村 裕之 ${ }^{21}$, 執印 太郎”

【目的】腎細胞癌の発生においては、癌抑制遣伝子VHL、BHD や癌遺伝子 c-met 等の遺伝子変異が重要な役割を果たしてい ることが知られている。しかし、これらの遺伝子異常を示さな い腎綀胞癌も存在して㧍り、他の遺伝子の関与が示唆される。 今回我々は腎細胞癌患者の血液 DNA を用いて、腎綀胞癌発症 に関係する遺伝子の検索を行った。対象及び方法】本学附属病 院及び関連施設で腎細胞癌の診断を受けた患者のうち、イン フォームド・コンセントを行い、研究に対する同意を得られた 患者より血液を採取し DNA サンプルとした。対象遺伝子とし ては、 3 番染色体短腕の癌抑制遺伝子ラスターから、TGFBR 2、OGG1、RASSF1。また、腎臓は代謝産物の排泄器官であるこ とより、薬物トランスポーター(OCT、OAT、MDR、MRP) を候補とした。各遺伝子に存在する一塩基多型 (SNPS)をデー タベースから選び、PCR-direct sequence 法で遺伝子変異を解 析した。結果と考察】非家系疾患群に対し、SNPs 出現パター ンで連鎖不均衡が認められたものは、OGG1、OCT1、OAT4L、 MRP1、MRP2であった。この連鎖不均衡解析を元に対照群に ついても候補遺伝子のSNPs 解析を行い、腎細胞癌の分類と遺 伝子型頻度から相関解析の結果、OCT1などの遺伝子が腎細胞 癌の感受性候補遗伝子の一つと考えられた。

\section{APP-014 低酸菜刺激による督細胞洁漫洞能增強 に関与する遗伝子の DNA Chip 解析を 用いた検討}

\section{東京医科大学泌尿器科学教室 \\ 吉岡 邦彦, 大野 芳正,並木 一典,古賀 祥嗣, \\ 権藤 立男, 中神 義弘, 松下 一仁, 坂本 昇, \\ 松本 真由子, 青柳 賁一郎, 大堀 理, 秦野 直, \\ 橘 政昭}

【目的】低酸素状態で癌の浸润能が增强するという報告は多いが、緗胞に よって反応は異なる。我々は、低酸素に対する緗胞動態の異なる2種類の 腎絊胞癌緗胞の DNA chip 解析を行い、低酸素による㿋浸潤能充進に関与

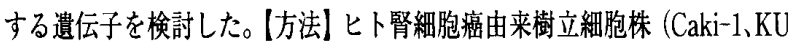
19-20)を用いた。低酸素状熊における紐胞動態は cell proliferation assay、 wound healing assay、matrigel invasion assay および adhesion assay を用 いて比較した。低酸素培盖 12 特間後に緿 RNA を抽出し、IntelliGene $2 \mathrm{Hu}$ man CHIP 1 (TAKARA BIO) を用いて DNA Chip 解析を行った。顕著な 発現変動を認めた遺伝子は RT-PCR 法にて再確認した。結果了低酸素で発 現が增强していた遺伝子は、Caki-1で203、kU19-20で248，低下した遺伝 子は、Caki-1 で 81、KU19-20で46 個あった。両細胞共に発現增強した遺伝 子は39個、低下した遺伝子は 6 個で、低酸素で発現变動した遺伝子は両細 胞株で大きく異なっていた。Caki-1 䋖胞でのみ発現增强した遺伝子で、特 徵的なのは、Apoptosis 関連、MMP family と Adhesion molecles 関連遺伝 子であった【結論】 低酸素下で発現变動する遺伝子は細胞により異なって いた。低酸素による癌浸润能增强の責任遺伝子として、Apoptosis 関連遺伝 子、MMP family と Adhesion molecles 関連遺伝子などが推湨された。

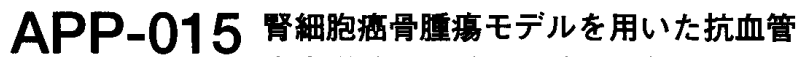 内皮增殖因子受容体（FIk-1）療法の梌 討}

\section{高知大学医学部腫瘦病態学堅泌尿器制御学教室", 高知

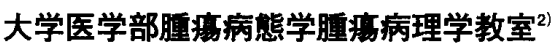

辛島 尚 ${ }^{12}$, 井上 啓史 ${ }^{11}$, 川田 千秋 ${ }^{1}$, 深田 聡”,

飯山 達雄 ${ }^{1}$, 執印 太郎" ${ }^{1}$, 倉林 睦 ${ }^{2}$

腎細胞癌の骨転移に対しては外科的治療以外確立した有 効な治療法は現段階では存在しない。腎細胞癌骨転移に 対する抗 Flk-1 療法による効果とそのメカニズムを明ら かにすることを目的とした。以下の検討には、ヒ卜腎細 胞癌骨転移巣より樹立された RBM-1 細胞を用いた。 RBM-1 細胞は、他の腎細胞癌株と比較して相対的に VEGF を高発現している。胸腺無形成ヌードマウスの䅡 骨ならびに腎歲に同所移植したモデルを用いて抗 Flk-1 チロシンリン酸化阻害郕 TSU-68 の効果を検討した。 $\mathrm{RBM}-1$ 細胞移植 3 日後より TSU-68 を連日経口投与し た。腎腫瘍モデルにおいては有意差をもって抗腫瘍効果 を示したのに対し、骨腫瘍モデルにおいては明らかな抗 腫場効果ならびに骨溶解阻害効果は認められなかった。 マウス破骨前駆細胞は Flk-1 の発現は示すものの TSU68 による直接的な細胞増殖抑制効果は認められなかっ た。破骨前駆細胞にとって Flk-1 はサバイバルファク ターではなく、腎細胞癌骨腫瘍モデルに打ける抗 Flk-1 阻害療法抵抗性の一つの要因と考えられた。

\section{APP-016 督癌細胞の腫满漫浯リンパ球からの B 7-H1 を介する免疫逃避機構}

熊本大学大学院医学薬学研究部泌尿器病態学分野", 東 京医科歯科大学医歯学総合研究科分子免疫学分野 ${ }^{2}$, 九 州大学大学院胸部疾患研究施設3), 熊本大学大学院医学 薬学研究部免疫識別学分野

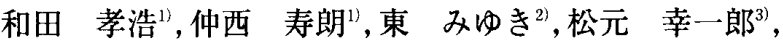
松吉 秀武", 西村 泰治"

【目的】腎癌における B7-H1を介する免疫逃避機構について梌討した。 【方法】腎癌患者から摘出した正常腎組織・腎癌組織・末梢血リンパ球 (PBL) を用いて B7-H1 とその受容体の1つである PD-1に対し免疫染 色・フローサイトメトリー・トリパンブルーアッセイ・クロムリリース アッセイによる解析を行なった。結果!すべての腎癌組織に B7-H1の発

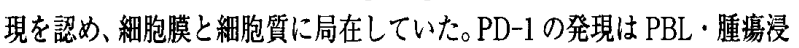
潤リンパ球 (TIL) で認めたがその発現はTILにおいて CD8 陽性および CD4 陽性 T cell でともに upregulate されていた。腎癌細胞と TIL の共 培養に捄いてトリパンブルーアッセイを行ったが抗 B7-H1 抗体を加え たものでは生存りンパ球数が増加・生存癌細胞数が著明に減少してい た。クロムリリースアッセイでは TIL 刺敫し、抗 B7-H1抗体を加える と癌絊胞に対与る細胞障害性が得られた。[結論]腎癌細胞住 B7-H1を介 する機序で TILを障害または增殖抑制し、TILの有する紐胞障害性から 逃避していると考えられた。TLは腎癌細胞に対して細胞障害性を有す るがこの機能仗腎癌緗胞の B7-H1 を介する機序で抑制されていると考 えられた。TILでの PD-1の発現が upregulateされていた事より腫場内 睘境ではリンパ球は B7-H1を介する影響を受けやすいと考えられた。 